\title{
Lo Stretto: tensioni
}

\author{
Claudio Marchese
}

Abstract

Binomi di sguardi: i riflessivi ed i rivolti all'esterno, hanno convissuto nel luogo-paesaggio Città dello Stretto ed hanno "strutturato" ad un destino, all'idea ossia, di qualcosa che fosse meno di un, Paesaggio dello Stretto, ed in ciò, un più.

Testimonia l'anelito alla complementarietà delle due sponde dello Stretto l'acquarello del collega Fabrizio Ciappina, preconizzante un punto di vista dimezzante stabilmente le distanze: la città di interscambio Morgana.

II termine che faceva da spartiacque tra gli studenti di Architettura solcanti giornalmente lo Stretto era "conurbazione": attorno a questo termine si tendevano le questioni del "mantenimento dell'identità" verso le ragioni di un "destino comune" di cui prendere consapevolezza, e, non secondariamente: dotarsi, intelligentemente, evitando duplicazioni, di una maggiore varietà di servizi di grande scala.

Ma, va ricordato che, negli anni '70, Reggio Calabria muoveva verso il riconoscimento del suo ruolo di capoluogo di regione, così, solo l'aeroporto si candidò ad essere "dello Stretto".

La prospettiva temporale può dar ragione della compatibilità delle due istanze, l'identitaria del ricordo e la comune della memoria. Chissà se ulteriori scostamenti in tal senso seguiranno, sino a fonderle e, se ciò sia, il meglio. $O$, il meglio stia nella costante tensione al compimento, come nell'infinitamente rimandato contatto delle dita di Adamo e Dio nella michelangiolesca creazione del Giudizio Universale!

Parole chiave

racconto, paesaggio, attraversamento, connessioni, Stretto di Messina.
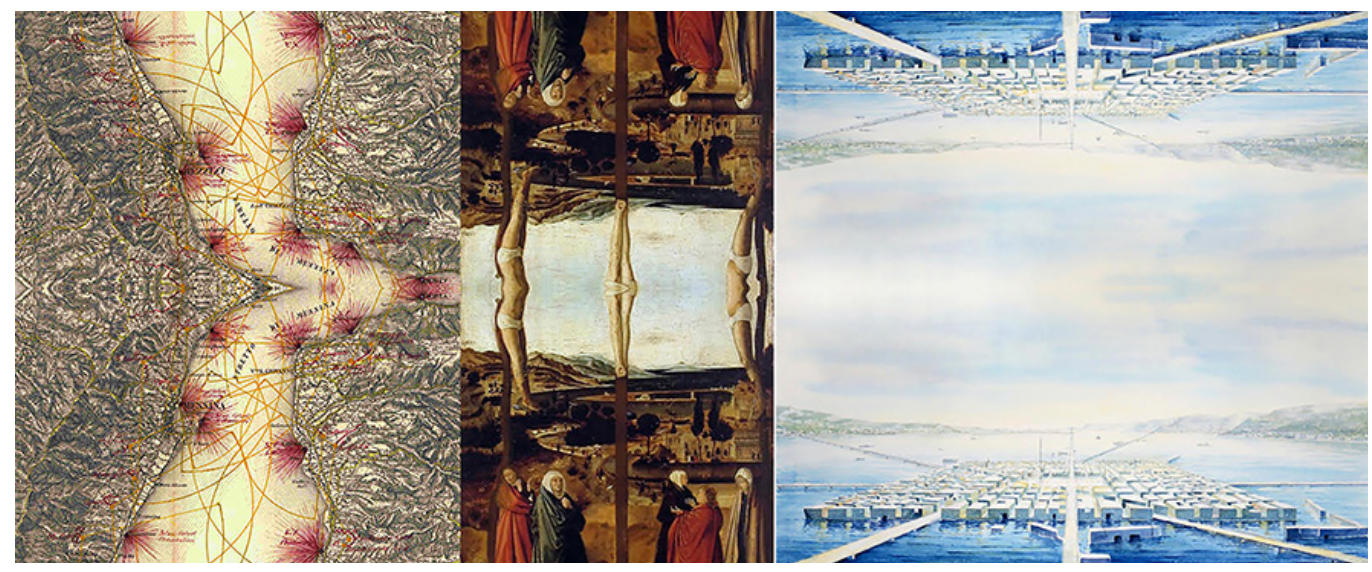


\section{II racconto: \\ Ricordo e Memoria}

Due forme di racconto qui si alternano: alla più personale, il ricordo, si alterna a quella presumente se stessa come oggettiva e riassuntiva, la memoria collettiva.

II Ricordo è affidato prevalentemente al linguaggio della scrittura che è capace di sondare il difficilmente rappresentabile figurativamente e la Memoria è affidata prevalentemente al linguaggio della figurazione per la sua capacità di imprimersi e comunicare per sintetici segni-immagini a tanti.

Tre paesaggi dello Stretto

Ecco detta la struttura che presiede al dialogo, almeno a quello visivo, rafforzato dai presidii dei forti Umbertini che hanno dotato lo Stretto di Messina, di un solido apparato visuale (cover a), capace di moltiplicare le "battute" conoscitive dei luoghi, come in un rilievo strumentale, sino a costituirsi paradigma, affiorante alla coscienza, della civiltà umana che vi si sviluppò ed ancora potrà.

È compreso ciò, da Antonello da Messina, nelle cui opere sono ritratti scorci del paesaggio dello Stretto, a far da sfondo-protagonista, nelle sacre rappresentazioni, come nella Crocifissione, detta di Sibiu (cover b).

Oggi, l'acquerello dell'artista-architetto Fabrizio Ciappina, che rinominerei "Morgana" (cover c) per il suo materializzare l'anelito del fenomeno manifestantesi a volte nello Stretto, pone nella grande Piazza d'acqua dello Stretto, nel suo centro, una tessitura urbana con una pluralità di connessioni alle sponde.

Ecco giunto nel centro dello Stretto lo snodo delle potenziali connessioni urbane, l'altro, l'alterego comune: la coppia di sponde-binari dello Stretto l'hanno eletto a connessione e scambio.

È la forza e il privilegio delle strutture binomiali, ben valorizzate da Gianni Rodari, nel suo "La grammatica della fantasia" a produrre terzietà.

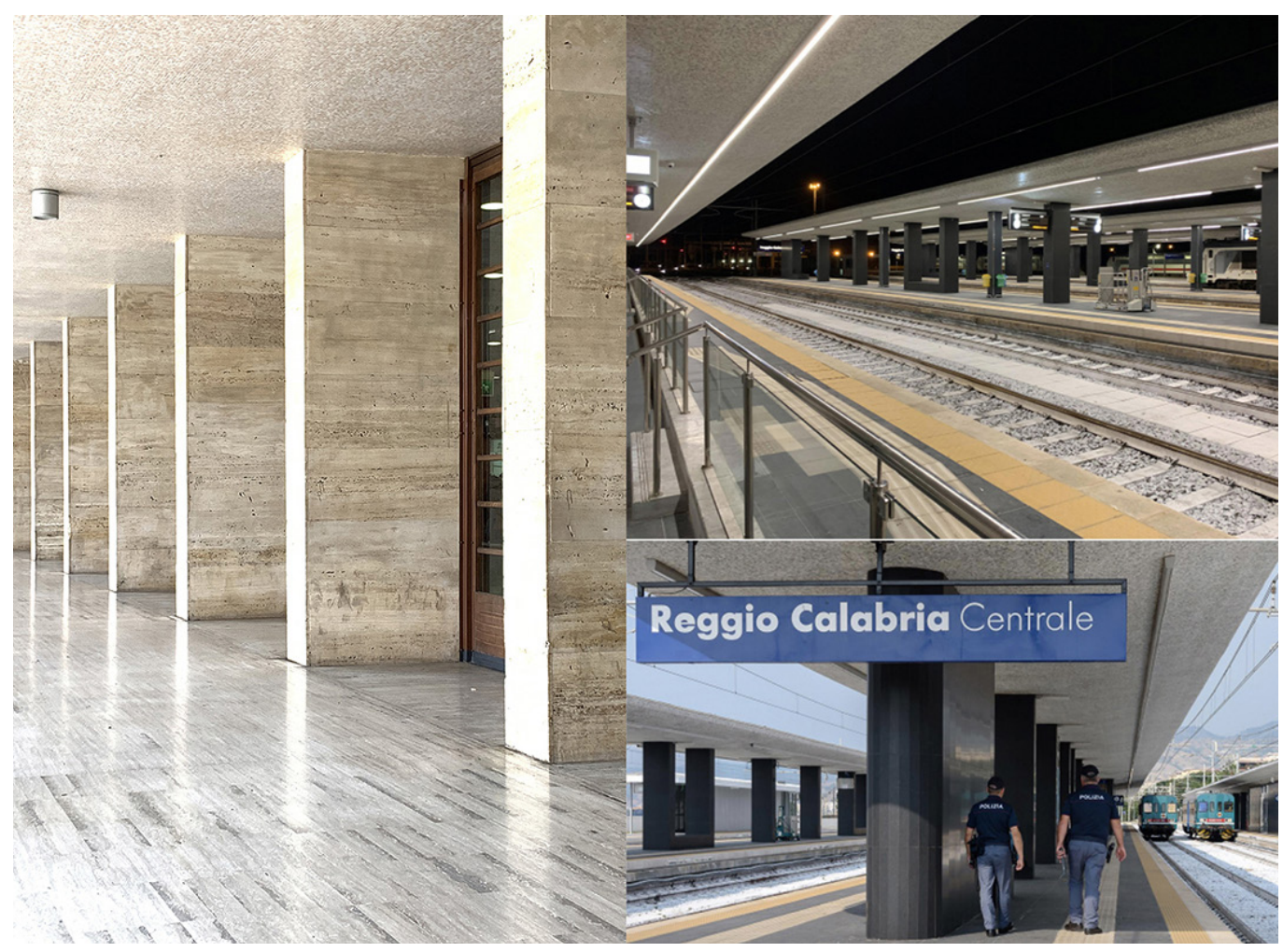




\section{Ricordo: \\ lo Stretto è luogo di rilievi cui si affidano narrazioni, in forma di aforismi, della città di Morgana.}

Il doppio

nella replica differente di analoghi sullo Stretto

Un doppio, dialogante, lo progetta e realizza Angiolo Mazzoni, per le stazioni ferroviarie gemelle di Messina (fig. Ia) e Reggio Calabria (fig. Ib): la bianca, in Travertino e la nera, in Pietra Lavica. Grandi sbalzi delle pensiline ad ala di aeroplano e, scambiate, contaminate, per materiali costitutivi, cilindriche e spiralmente avvolte da scale, le torri dell'acqua.

Unire e dividere

le Palazzate messinesi ed il Lungomare reggino con profilo gradonato: separatezze e coesioni

Alla cancellazione della Palazzata iuvarriana (fig. 2a) dello Stretto, seguì la Palazzata di Messina, dovuta principalmente a Giuseppe Samonà (fig. 2b): quest'ultima, oltre che presentarsi discontinuamente costituita da architetture declinanti differenti forme di espressione architettonica contro la ripetizione del partito compositivo che caratterizzava la precedente, si fermerà a presidiare la Piazza d'acqua del porto di Messina, chiuso nel perimetro della Falce, laddove il progetto dello luvarra si estendeva sino a Pace e proiettava i suoi effetti sino a Sant'Agata e Ganzirri, dichiarando sostanzialmente di voler farsi fronte di definizione dell'intero stretto, sul versante siciliano.

Ciò che è accaduto, non è una mera riduzione, è un cambio di prospettiva: la nuova Palazzata identifica la Piazza d'acqua del porto di Messina, non coinvolge più lo Stretto e quindi non persegue più l'obiettivo di unificare le due sponde e con esse le città che vi si affacciano: riguarda solo Messina.

Della precedente Palazzata, all'inverso: materiali artistici letterari, e di altre nature, testimoniano di come la piazza, "interno" tra due regioni e anche tra due mari generanti il taglio della corrente, sia luogo che mescola, unisce, ancor più di quanto, per via della sua consistenza acquea, divida.

L'altro segno riguardante lo Stretto, il Lungomare della via Marina a Reggio Calabria (fig.2c), che permane indenne: la sua fortuna potrebbe essere stata determinata dall'espressione formulata da Gabriele D'Annunzio "Il più bel chilometro d'Italia", e, non secondariamente, dalla sua morfologia lineare e dai materiali costitutivi di natura vegetale, gli alberi.

La linea che segue la costa, mai richiudentesi, ne ha interdetto la possibile, esclusiva, appartenenza alla città, anche se, la dislocazione nello Stretto della città di Reggio Calabria, in una porzione in cui l'invaso dello Stretto è in una minore tensione per la maggiore distanza tra le due sponde, ne sminuisce la forza contenitiva, se non anche la marginante per via della esiguità d'estensione rispetto alla scala della grande Piazza dello Stretto.

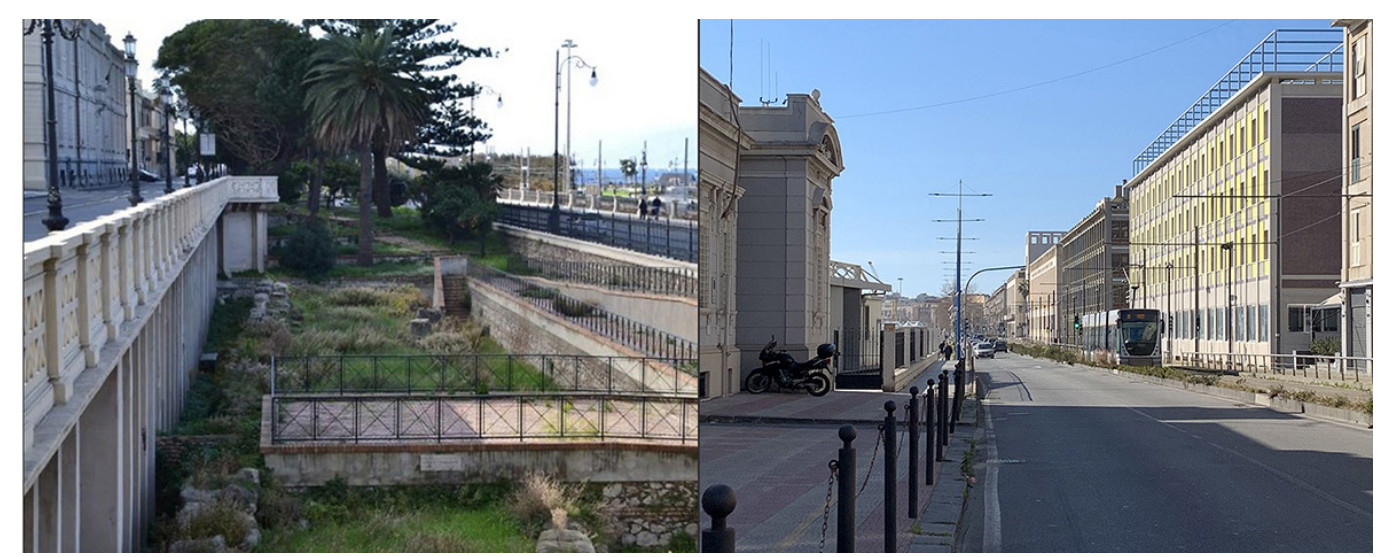


Laddove manca l'estensione, è invece potente il rafforzamento della linea in spessore, per via di tutta la tessitura urbana, disposta su molteplici gradoni, in virtù dei quali, i piani alti dell'edificazione, già dal corso principale, godono dell'affaccio sullo Stretto. Allo Stretto, così privatizzato, fa da potente contraltare il sistema delle risalite con scale a tenaglia e relativi pianerottoli estesi, che offre terrazzi pubblici la cui mira è spesso contenuta tra quinte istituenti cannocchiali ottici (fig. 2d), mire su porzioni, frammenti di Stretto.

La ricchezza insita nella morfologia: terrazzi subito risalenti dalla stretta striscia in piano a ridosso della costa, è nella doppia offerta di visione, lo sguardo aperto del Lungomare, sull'insieme dello Stretto, da un suo margine e la descrizione analitica di frammenti dello Stretto, anche se per un, relativamente breve, tratto, in cui inquadra significative porzioni della città dirimpettaia.

Da quanto su, traspare ciò che nei fatti è stato il modo di rapportarsi delle due identità urbane: Messina che, forte della sua caratterizzazione morfologica, con il suo porto naturale ha calamitato persone ed attività, tra cui l'antico centro di studi universitari, Reggio Calabria che ha potuto far altrettanto grazie al suo patrimonio storico conservato oltre che nel prestigioso Museo, anche negli scavi in sito sul, già citato, più bel chilometro d'Italia. Avrà un senso che, ceppo originario degli studi universitari reggini sia stata proprio una Facoltà di Architettura. Un patrimonio, quello reggino, meno cancellato dai traumatici eventi di terremoti e maremoti dello Stretto, rispetto a quello messinese, probabilmente per il suo facile ricrearsi dovuto alla natura vegetale ed al conservare la sostanza materiale delle, già rovine, greche e romane.

\section{Attraversamenti:}

misuratori di realtà in mutamento

La testimonianza che trovo più sensibile, del luogo Stretto come spazio di transito, sta negli insistiti disegni (fig. 3) che ritraggono, per lunghi anni, giornalmente, in punta di rapidograph, navi, barche, aliscafi, che continuamente lo solcano.
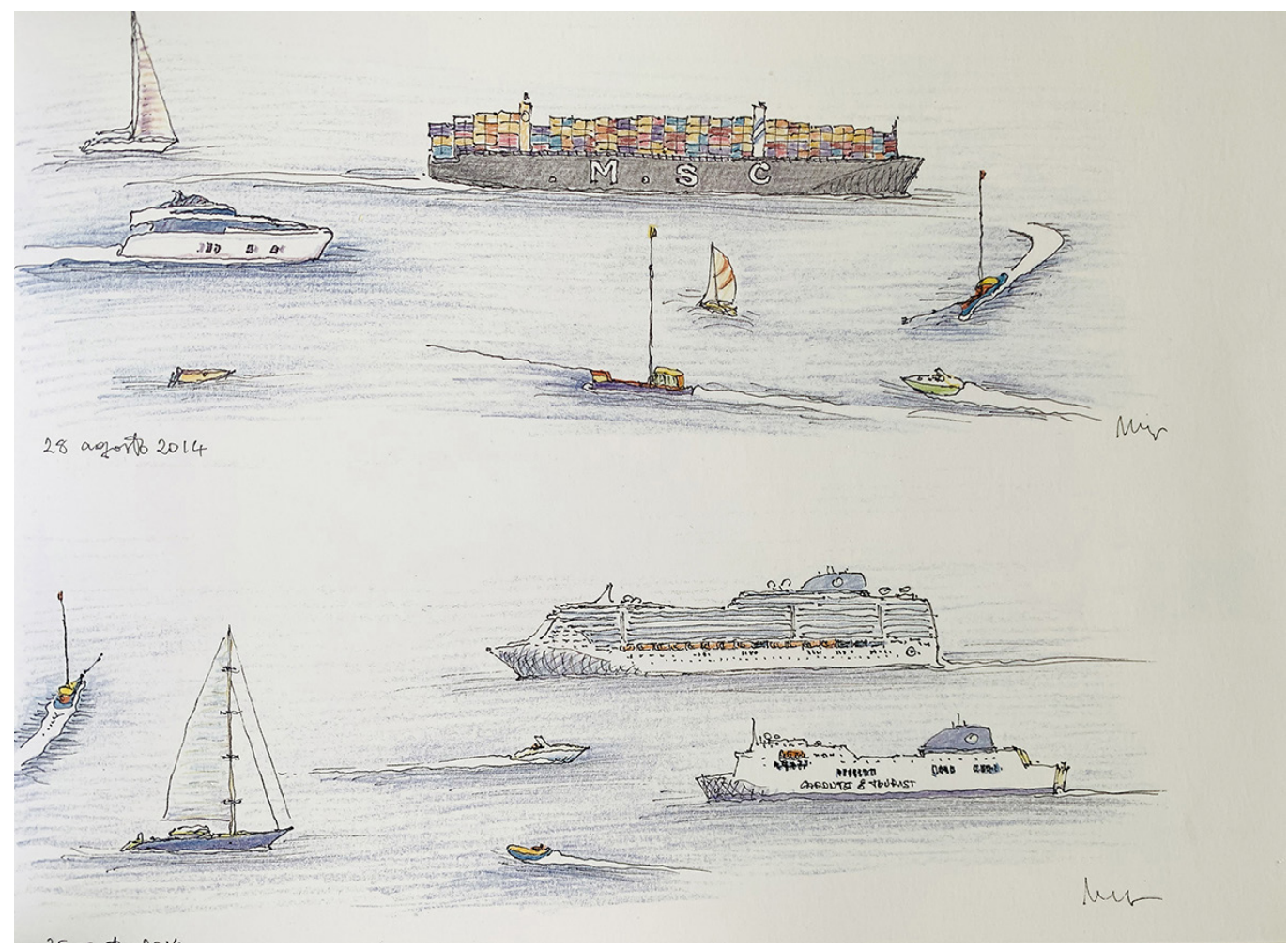
Mario Manganaro, il contemporaneo disegnatore più intensivo del Paesaggio dello Stretto, ne ha prodotti una innumerabile quantità, negli anni e, più volte anche, nel ricorrere settimanale delle rotte mercantili, ha ritratto il riproporsi di abituali frequentatrici dello stretto. I disegni raccontano un movimento, testimoniano di una vivacità degli attraversamenti che, continuamente muta il paesaggio. I disegni testimoniano anche che, il paesaggio viene molte volte indagato da tanti occhi, anche quelli, in movimento. Occhi sullo Stretto, loro si, registratori dei cambiamenti ma anche, misuratori, con lo sguardo del paesaggio dello Stretto, degli altri paesaggi che si va a visitare per imbarcare le merci che poi, da qui, transiteranno.

\section{Connessioni}

per il tramite dei fronti: da indefinitezza e protensione

Tra i progetti che meglio interpretano la tensione ad aprirsi alla realtà dirimpettaia, due: la riprogettazione del lungomare reggino a firma di Sandro Anselmi e l'idea-progetto di Francesco Venezia in occasione del simposio sull'Isolato urbano messinese.

Media il rapporto tra il lungomare alberato decantato da D'Annunzio come il più bel chilometro di fronte a mare e la mutevole linea del bagnasciuga della spiaggia lambita dall'acqua dello Stretto, il progetto di Alessandro Anselmi (fig. 4a).

Ortogonale rispetto alla costa è il segno sul fronte messinese posto dal progetto di Francesco Venezia (fig. 4b) che, tridimensionalizza l'alveo di uno dei torrenti messinesi, quello del Portalegni, concludendolo, con il grande edificio sbalzante sullo Stretto, oltre il labile confine del bagnasciuga. Edificio proteso, questo terminale, nell'ipotesi di potenziali repliche, indotte dalla struttura del paesaggio, segnata dai torrenti ortogonali alla costa, darebbe il senso dell'affaccio sulla grande piazza d'acqua dello Stretto ed oltre.

Fig. 4. II fronte verde e la connessione con la spiaggia del progetto di Alessandro Anselmi per Reggio Calabria ed il proteso edificio di Francesco Venezia scavalcante il fascio di binari oltre il Portalegna a Messina.
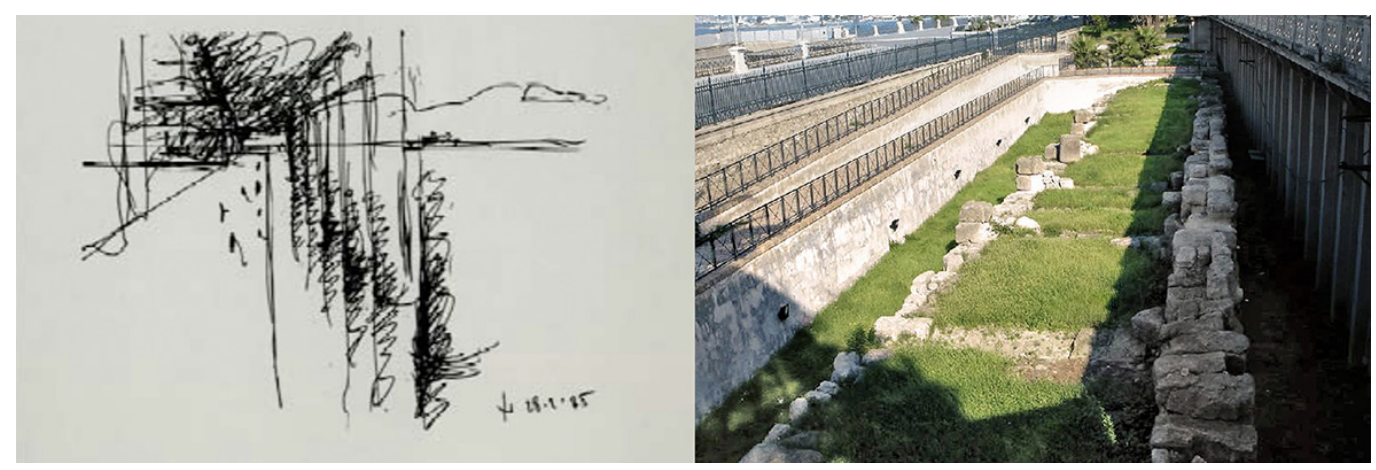

Sensibilità al Moderno

ribadite in restauri-riabilitazioni di luoghi dello Stretto

Non mancano anche i rilanci mossi attraverso la realizzazione di restauri di aree ed edifici testimoni del recente passato: il lido di Reggio Calabria (fig. 5a), di Bruno Zevi e la più articolata cittadella fieristica messinese con edifici di Adalberto Libera (fig. 5b), i cui restauri, in corso, ed adeguamenti normativi, vedono impegnati lo studio Purini-Thermes, coadiuvato dal messinese Massimo Lo Curzio. Le parti di cantieri già chiusi, mostrano, assieme al rigore filologico, proprio quella sensibilità agli scostamenti concettuali che ha portato alle necessarie aggiunte, adeguamenti alle richieste di norme sulla sicurezza ed il risparmio energetico e di cui, nello specifico, non si può dir altro che: sono come fossero sempre state lì, il che è maggior apprezzamento per il lavoro compiuto. 
Fig. 5. II Lido di Reggio Calabria e la Fiera di Messina, progetti e restauri di testimonianze del Moderno sullo Stretto.

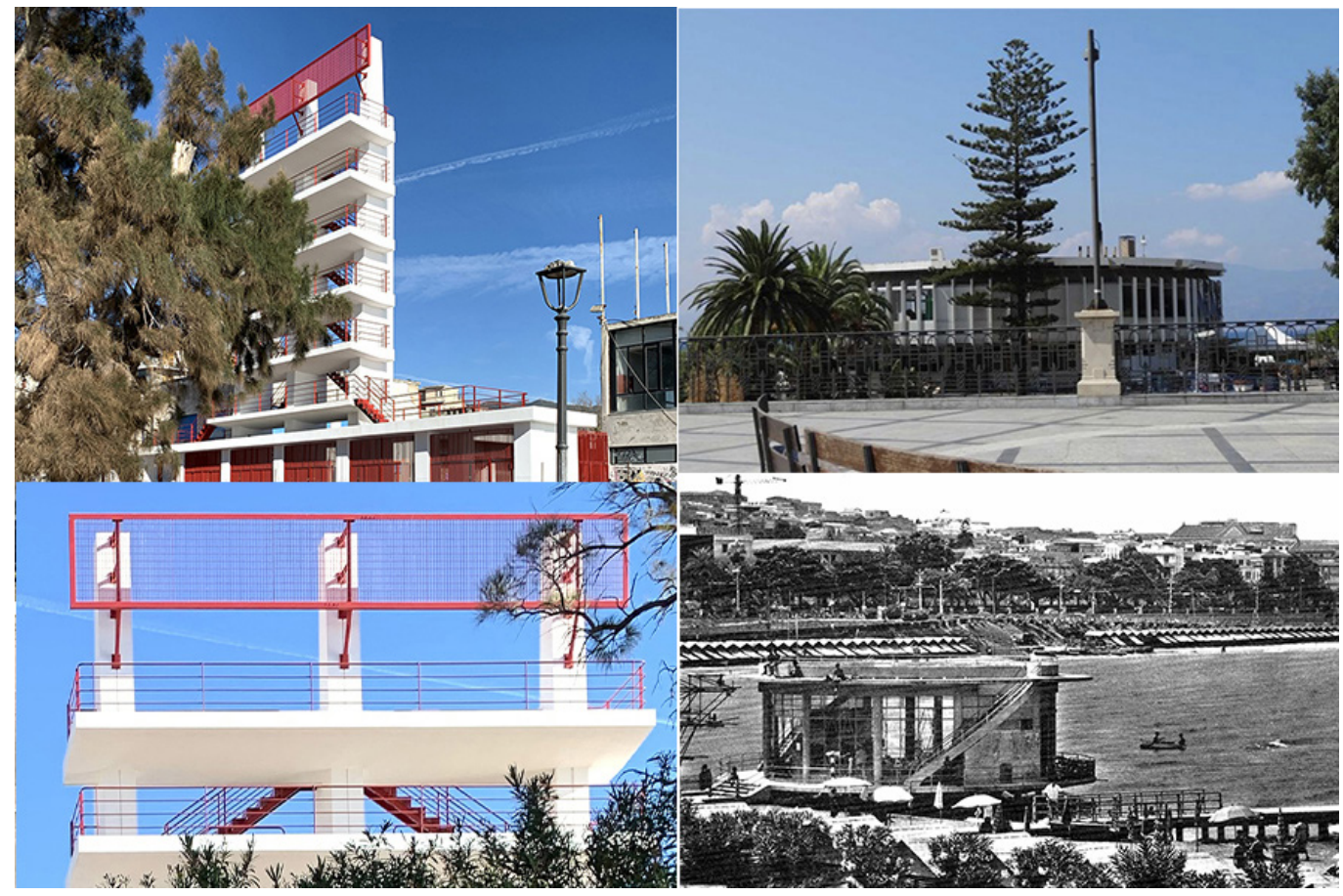

Porta dello Stretto:

concorsi progettuali per un luogo singolare

Azioni, rimaste sulla carta, fanno non meno che da testimoni di un grado di elaborazione sensibile ai caratteri e storia dei luoghi. Uno specialissimo esempio, per dislocazione, ha riguardato un concorso progettuale denominato "Capo Peloro" ed ha impegnato molti professionisti con idee emananti dall'intima conoscenza dei luoghi.

Ne testimonio, questa volta dall'interno, avendo fatto parte di un gruppo che ha visto il già citato Prof. Mario Manganaro assieme a suoi ritrovati colleghi di studi romani: le Professoresse, Maria Anna Caminiti ed Elena La Spada, militanti prima ad Architettura di Reggio Calabria e poi ad Ingegneria di Messina, assieme a più giovani leve tra cui stavo.

Più questioni sono state soggetti del Progetto di concorso di quel nostro gruppo di lavoro, presentato con il motto Arcalamecca, memoria dell'espressione in uso nei luoghi per esprimere stupore per qualcosa di veramente bello e di grande rilevanza nello spazio: un "Fenomeno", come, ricordiamo, la Fata Morgana che, in particolari condizioni atmosferiche mostra capovolte, specchiate sull'acqua ma anche sospese nel cielo, città e costa.

L'azione più naturale è il rafforzamento della forma di legame che le schiere di case tengono con gli appezzamenti lineari di identico spessore della casa, i giardini antistanti e sul retro ricalcanti le tessiture agricole del piano contenete anche i laghetti di Ganzirri.

Specialissimi invece, per singolarità dello specifico punto estremo che le accoglie, il "Finis Terrae", le architetture-luoghi: dell'ascolto del mare, un orecchio istituito formalmente da un complesso di meridiani e un piccolo osservatorio sottomarino, altra conchiglia, espressa spiraliformemente, immergentesi lì, a Capo Peloro (fig. 6a).

Ancor più sintetico l'intervento ideato da Sandro Anselmi per l'altro stipite della porta dello Stretto: in cima al Castello di Scilla, di per se, presenza rilevante, null'altro che accenderlo di figurazioni del mito, il che suscita subito un afflusso di rimandi: mito e vita di questo specialissimo tratto di mare presidiato per l'appunto da Scilla e Cariddi (fig. 6b). 
Fig. 6. Un concorso progettuale testimone del forte legame tra vita e mito, sullo Stretto ed un "faro-incantatore" sul Castello di Scilla.
Fig. 7. Edifici e altre attrezzature che riconfigurano gli assetti urban rafforzando i luoghi de confronto, delle città dello Stretto: Palacultura (Me), Uffici della Regione $(\mathrm{Rc})$, linea del Tram (Me) Aeroporto (Rc) (composizione).
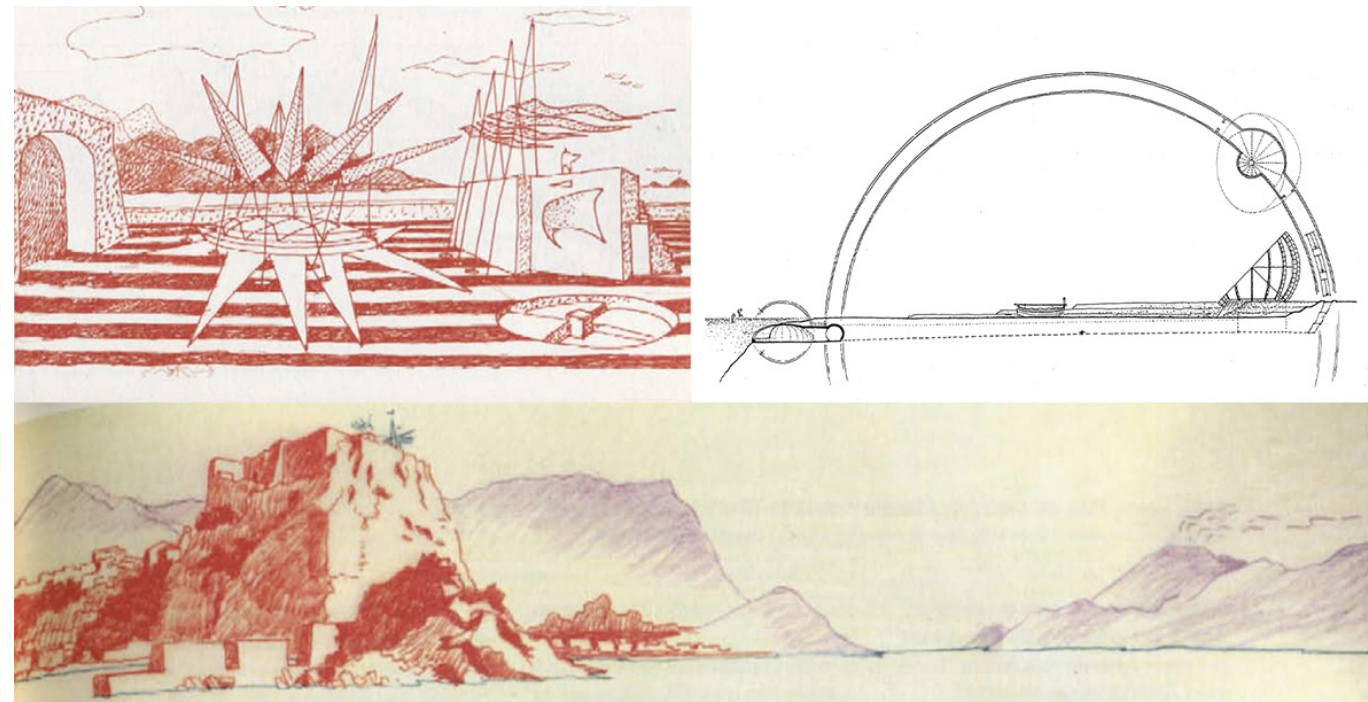

Riconfigurazioni urbane:

interventi pubblici, nuove dotazioni

Reggio Calabria nel mentre ha consolidato il sistema del suo polo universitario con i campus di Architettura, Ingegneria e, sulla collinetta più in alto, Agraria. Ha preso consistenza ed occupato altre edificazioni anche Giurisprudenza. Anche le istanze per ospitare il Consiglio Regionale hanno avuto esito con la nuova sede ed altrettanto il Centro Amministrativo, dando strutturazione ulteriore e non trascurando il nuovo allestimento espositivo del bel Museo dovuto a Piacentini, che rilancia la città nel panorama delle città d'arte, prestigiosamente, per le collezioni riguardanti la Magna Grecia.

Messina si è dotata del suo PalaAntonello, palazzo della cultura che assieme al rinato Teatro Vittorio Emanuele, ed all'omonima Galleria, promette rinascita del richiamo dei suoi cittadini a fruire con più intensità la città ora capace di accogliere eventi che potenzialmente potrebbero rinverdire i fasti passati dell'esser sede del festival del cinema che si teneva nella cittadella fieristica, e che allora era, di Messina e Taormina. La mobilità urbana ha acquisito, anche questa una riedizione, la sua metropolitana di superficie che lega velocemente due suoi poli posti a terminali delle scandite presenze rilevanti distribuite sulla costa (fig. 7).
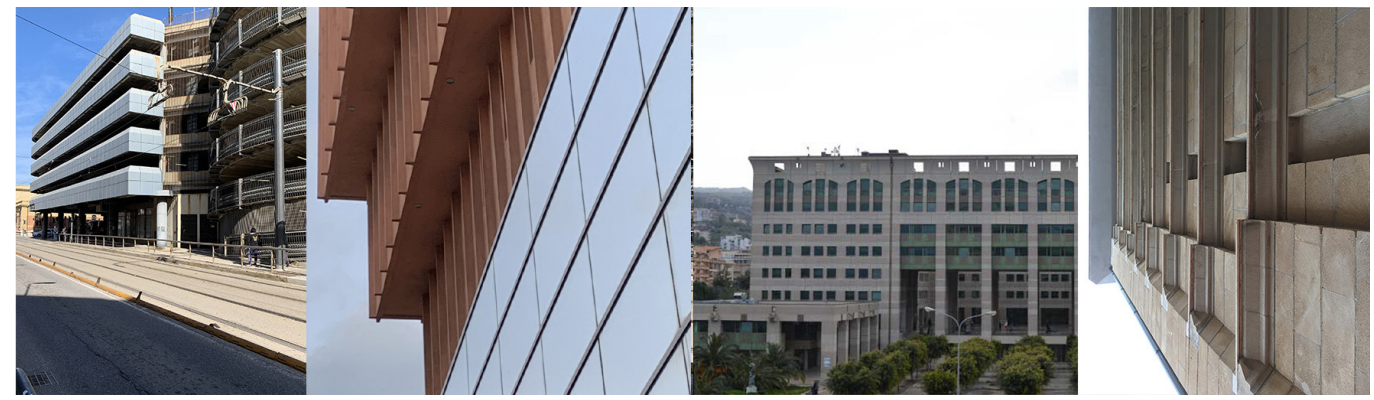

Lo Stretto presidio del connettere:

i Piloni dell'ex attraversamento stabile di energia elettrica sullo Stretto, torri panoramiche per l'abbraccio in un sol sguardo della sua estensione.

Su entrambe le sponde, la conurbazione urbana è avvenuta, di fatto, e si torna a prestare attenzione alle fortezze, ai Forti Umbertini, che, oggetto di studio nei Workshop Woz, proveranno, assieme alla struttura fortificata in Piazza Castello entro il centro urbano reggino 


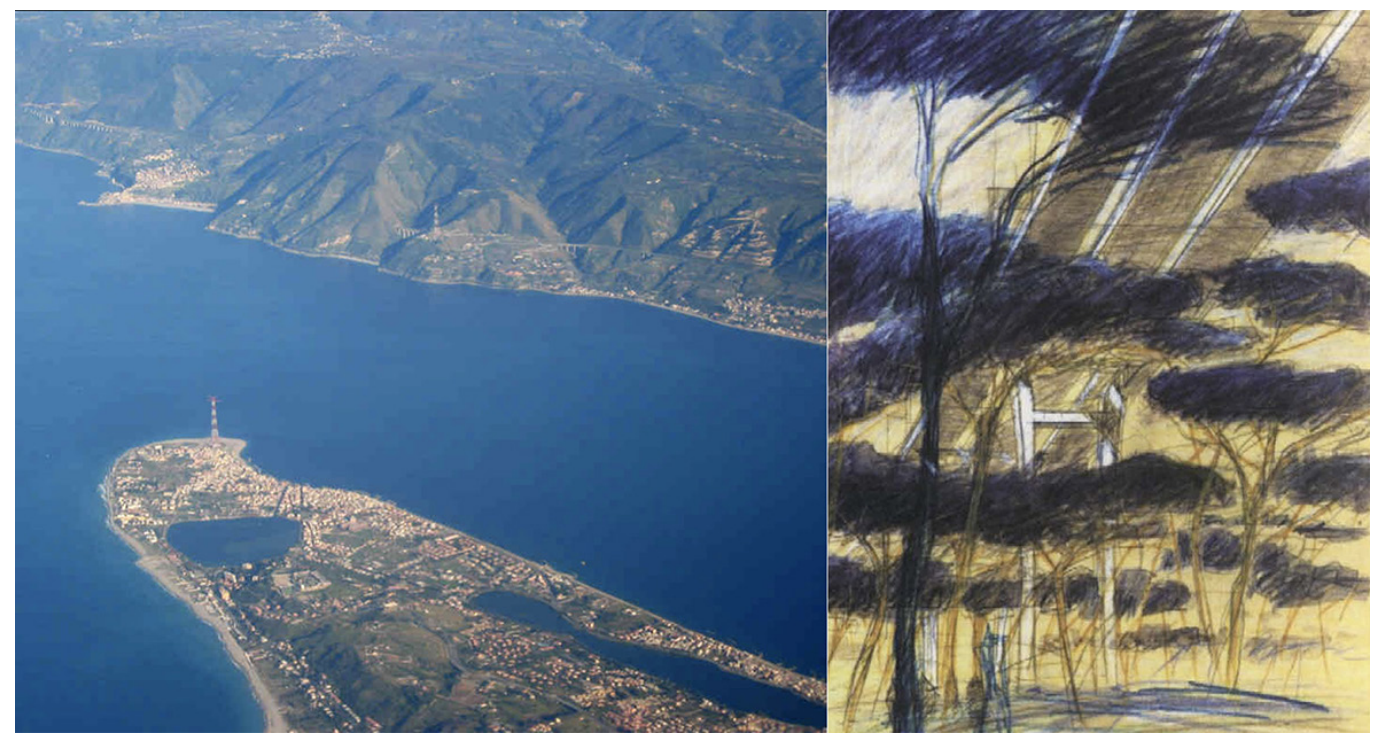

ed il Castello di Scilla, con le grandi figurazioni ideate da Alessandro Anselmi per il terrazzo sul mare, a testimoniare l'anelito ad un comune destino, estrema propaggine dello Stretto verso nord, segnante la punta oltre la quale, sul fronte calabro, non è più Stretto.

Testimoni muti dell'unico attraversamento stabile, non più attivo, quello di energia elettrica, i due Piloni, il siciliano sulla punta di Torre Faro ed il calabro sulla collinetta di Punta Cavallo, in rari casi visitabili, straordinari punti panoramici (fig. 8), confermano l'appartenenza ad un unico paesaggio, come lo sguardo che da essi si apre, afferma.

Sguardo che viaggia oltre la grande Piazza d'acqua, poiché il suo continuo attraversamento connette luoghi e culture fisicamente distanti come, da sempre, questi luoghi del mito, che per l'appunto Scilla e Cariddi si nominano e della leggenda di Colapesce nutrendosi, attuano. Confermano anche la fragilità e la resistenza dei luoghi molto attraversati da rotte che si spinsero oltre le colonne d'Ercole, ossia oltre i confini del mondo antico.

Dall'antichità classica del tempo del mito, incessantemente connettendo civiltà, come testimoniato dai fiorenti studi delle università sulle due sponde, ospitanti tanti migranti della cultura, si continuano ad intrecciare storie.

\section{Conclusioni}

Le terre che furono colonizzate dalle migrazioni dei provenienti dalle città-stato greche, i cui protagonisti si mescolarono con le popolazioni autoctone, il carattere del connettere mescolando, conservano e l'essenza di testimone di civiltà multietnica in perenne mutazione, perpetuano. 


\title{
The Strait (of Messina): Tensions
}

\author{
Claudio Marchese
}

Abstract

Binomial gazes: the reflective one coexisted in the place-landscape that is the City on the Strait and they have "structured" the city to a destiny, or better to the idea, of something that was "less" than a Strait Landscape and, for this reason, a "more".

The watercolor made by our colleague Fabrizio Ciappina testifies the yearning for a complementarity of the two sides of the Strait in proposing a point of view that halves the distances in a stable way: the city of interchange, Morgana.

The noun that acted as a watershed among the students of Architecture who sail the Strait every day was "conurbation" (conurbazione, in Italian): around this term the questions of "identity maintenance" were raised towards the reasons of a "common destiny" to be aware of and then of acquiring intelligently, by avoiding duplication, a greater variety of large-scale services.

But, it should be remembered that in the 1970s Reggio Calabria was moving towards the recognition of its role as Regional Capital and, for this reason, only the airport applied to be the only one "of the Strait". The temporal perspective can explain the compatibility of the two instances, the identity of the reminiscence and the common of the memory. Who knows if further differences will follow in this direction, eventually in coming to merge them, and who knows if it will be the best way to do it; or perhaps the best will be inside the constant tension to its accomplishment, as happens in the infinitely postponed finger's contact between Adam and God of the Michelangelo's Creation in the Last Judgment! The Strait (of Messina): tensions
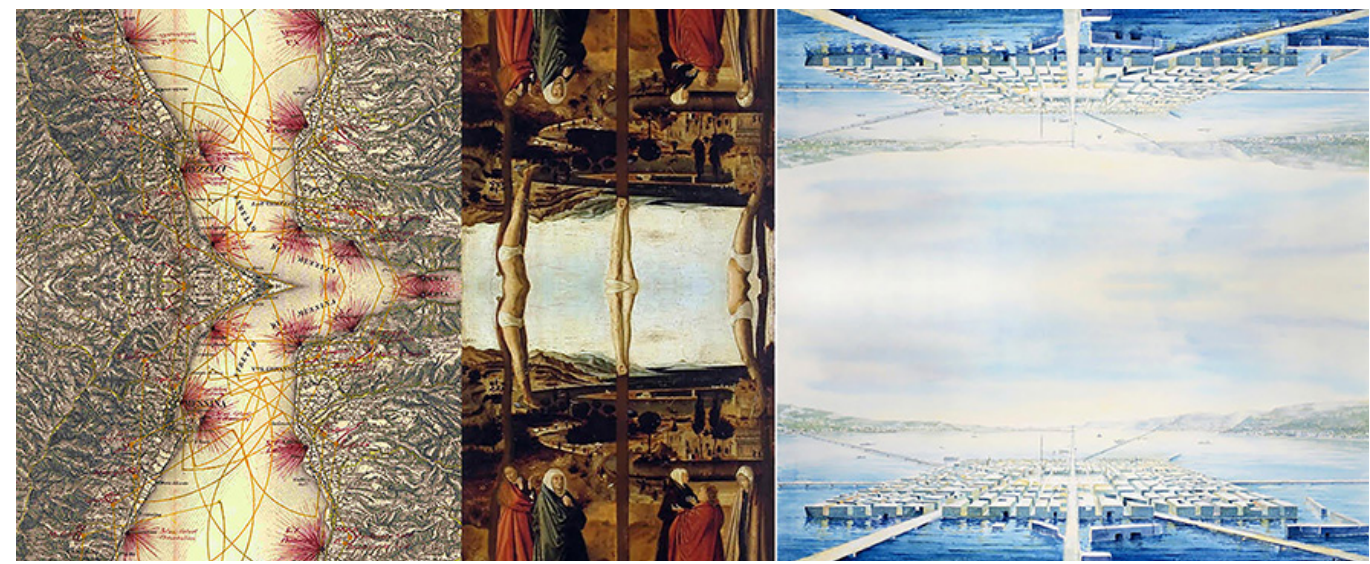


\section{The storytelling Reminiscence and Memory}

Two forms of story alternate themselves here: the most personal, the reminiscence, which temporarily replaces the other one that should be objective and summarized: the collective memory.

Reminiscence is mainly entrusted to written language, which is capable of probing what is difficult to represent in figurative form, and Memory which is mainly used in the language of figuration thanks to its ability imprinting and communicating itself through synthetic signs-images to a large public.

\section{Three landscapes of the Strait}

Here is a description of the structure that presides over the dialogue, at least over the visual one (cover a), strengthened by the military garrisons of the Umbertinian Age's forts that have equipped the Strait of Messina with a solid visual apparatus capable of multiplying the knowledge's "stations" of the places. As in an instrumental survey, becoming like a paradigm, that emerges from consciousness of the human civilization that has developed itself and will still be able to do again and again.

This was understood by Antonello da Messina, in whose works are portraits foreshortenings of the Strait's landscape, in background but as protagonists of sacred representations, such as in the Crucifixion, called "Sibiu's" (cover b).

Today the watercolor work of the artist-architect Fabrizio Ciappina, whom I would rename "Morgana" (cover c) for its materialization of the phenomenon that sometimes manifested itself in the Strait, places an urban texture, with a plurality of connections with its shores, in the center of the large Water Square of the Strait.

Here, in the center of the Strait, is the node of potential urban connections, the other one, the common alter-ego: the pair of shores-tracks of the Strait promoted it as a connection and exchange.

It is the strength and privilege of binomial structures, well valorised by Gianni Rodari in his The grammar of fantasy, that produces a third dimension.

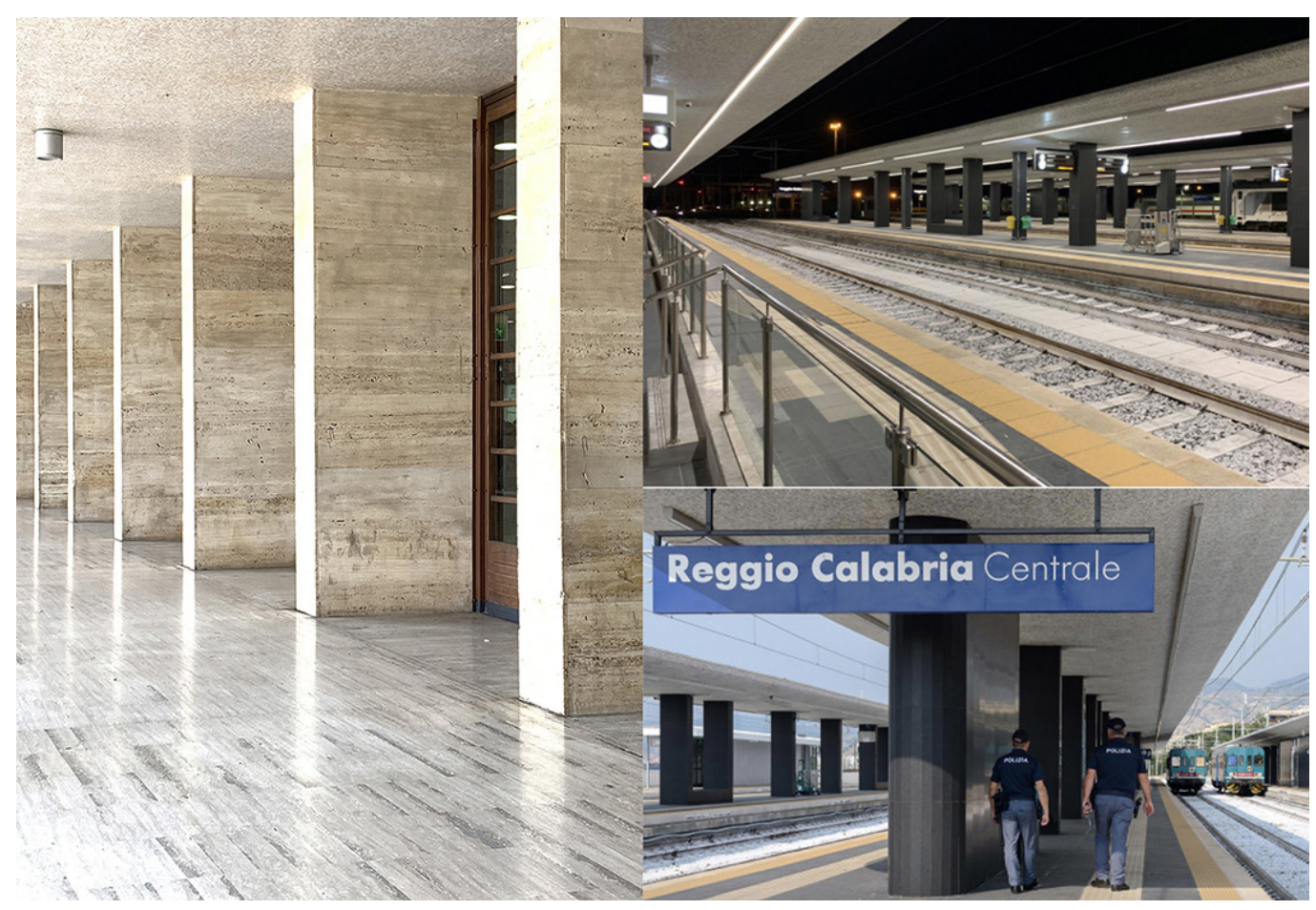


(A/The) memory

The Strait is a place of hilly reliefs to which entrust to narrations of the city of Morgana, in the form of aphorisms

The double

in the different replication of analogues on the Strait

Angiolo Mazzoni designed and built a double for the twin railway stations of Messina (fig. I a) and Reggio Calabria (fig. Ib): the white one, in Travertine and the black one, in Lava Stone. Large and overhanging canopies, shaped as airplane wing, and water towers, contaminated by constituent materials, cylindrical and spirally wrapped by flying stairs.

To join and to divide

The "Palazzate" of Messina and the seafront of Reggio with its protruding profile: separations and cohesions.

To the the cancellation of luvarra's Palazzata followed of the Palazzata of the Strait, mainly due to Giuseppe Samonà (fig. 2b): the latter as well as appearing discontinuously consisting of architectures declining different forms of architectural expression against the repetition of the compositional party that characterized the previous one, the latter will stop to guard the water square of the port of Messina, closed in the perimeter of the Falce, where the luvarra's project extended to Pace and projected its effects up to Sant'Agata and Ganzirri, substantially declaring that it wanted to be the vertical definition of the entire strait, on the Sicilian side.

What happened is not just a reduction, but a change of perspective: the new Palazzata identifies the water square of the port of Messina, no longer involving the Strait and therefore no longer pursuing the objective of unifying the two sides and with them the cities that look out over it: now it only concerns Messina.

The reverse is said for the previous Palazzata: literary, artistic, and other materials testify to how the square, "internal" between two regions and also between two seas generating the cutting of the current, is a place that mixes and unites, even more how much, due to its water consistency, it divides.

The other sign concerning the Strait, the seafront of the Via Marina in Reggio Calabria (fig. 2a) remains unscathed: its luck has been determined by the expression formulated by Gabriele D'Annunzio "il più bel chilometro d'Italia" (The most beautiful kilometer in Italy), and, not least, by its linear morphology and the constituent materials of plant nature, its trees.

The line that follows the coast, without ever closing itself, has prevented its possible exclusive belonging to the city of Reggio Calabria, even if its location in a portion where the Strait reservoir is in less tension, due to the greater distance between the two sides, diminishes its containing strength, due the tinier extension of the urban city of Reggio Calabria in front of the large Square of the Strait.

Fig. 2. The two 'Palazzate', the first belonging to the Square of Strait and the other one related to the urban square of Messina, and the two systems of the seafront with the optical telescopes of Reggio Calabria.

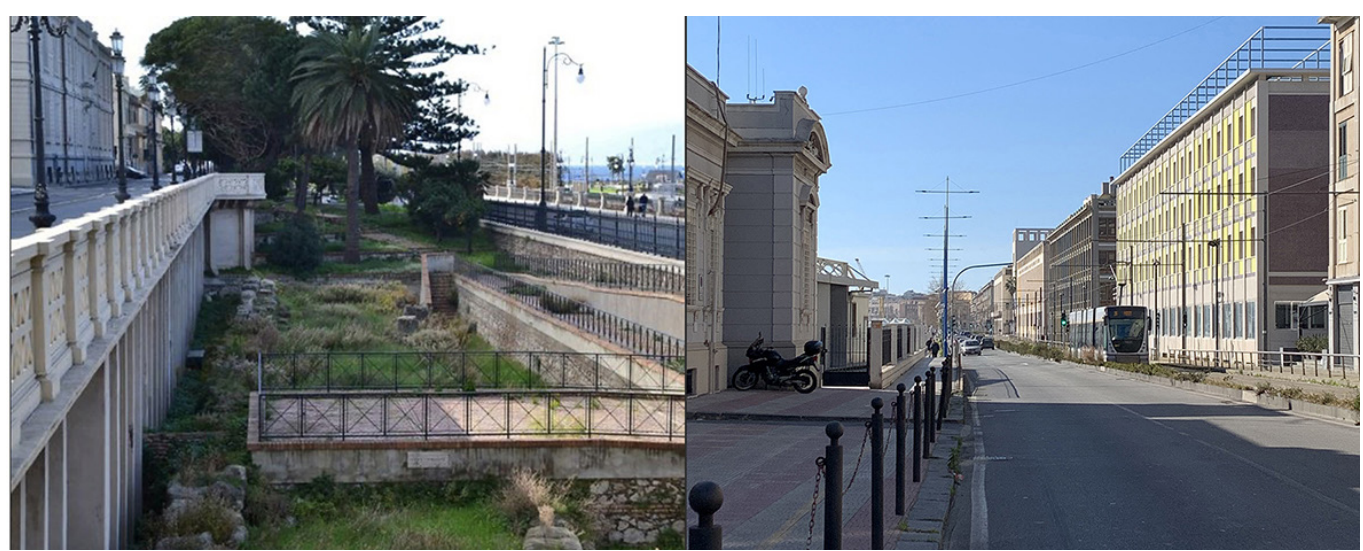


Where there is no extension, the strengthening of the line in thickness is powerful instead, due to the whole urban texture arranged on multiple steps, by virtue of which the high floors of the buildings, already from the main avenue, enjoy overlooking the Straits.

To the Strait, such privatized, the system of ascent ways makes a powerful counterpart: in fact the pincer ladders and related extended landings offer public terraces whose sight is often contained between some theatrical backdrop creating many optic telescopes, as portioned sights and fragments of the Strait.

The wealth is inherent in the morphology: terraces immediately starting from the narrow flat strip close to the coast, are, in the double vision, the open view of the seafront, on the whole of the Strait, from its margin and the analytical description of fragments of the Strait, even if for a relatively short stretch in which it frames significant portions of the opposite city.

From what has been said, it transpires what in fact was the way of relating the two urban identities: Messina which, thanks to its morphological characterization with its natural port, has attracted people and activities, including one of the most ancient university study center, and Reggio Calabria which has been able to do the same thanks to its historical heritage preserved not only in the prestigious National Museum, but also in the excavations in situ, on the aforementioned most beautiful kilometer in Italy. It will make sense that the original strain of the Reggio University of Studies was just the Faculty of Architecture. A heritage, the one in Reggio Calabria, less erased by the traumatic events of earthquakes and tsunamis in the Strait than that of Messina, probably because of its easy recreating due to the plant nature and the preservation of the material substance of the traces, already ruined, of Greek and Roman civilizations.

\section{Crossings}

meters of changing realities

The testimony that I find more sensitive of the Strait place as a transit space lies in the insistent drawings (fig. 3) which portray, for long years, daily, at the tip of his rapidograph, ships, boats, hydrofoils, which continually furrow it.
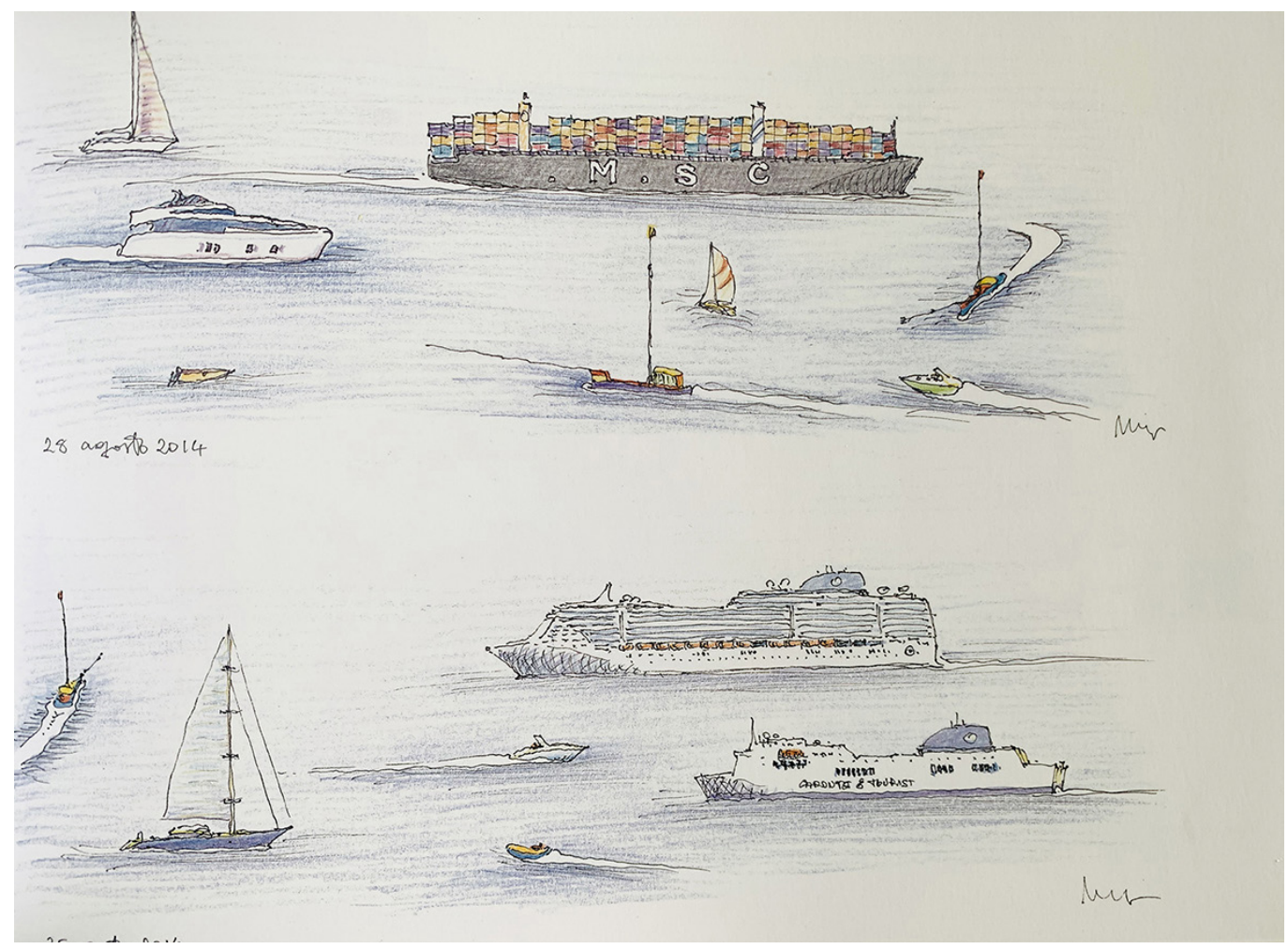
Fig. 4. The green front and the connection with the beach in Alessandro Anselmi's project for Regoio Clabria and the chosing

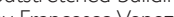
(lia climbing over the bund Pracks beyond the ortalegna creek in Messina
Mario Manganaro, the most intensive contemporary designer of the Strait Landscape, has produced an innumerable quantity of it over the years and, several times also, in the weekly recourse of the merchant routes, he has portrayed the repetition of habitual frequenters of the Strait. The drawings tell of a movement, testify to a liveliness of the crossings that continually changes the landscape. The drawings also testify that, the landscape is often investigated by many eyes, even those in motion.

Eyes on the Strait, them yes, as recorders of changes but also as measurers, with the gaze of the landscape of the Strait and of the other landscapes that are allowed to visit to embark the goods that will then pass.

\section{Connections}

through fronts: from indefiniteness to protension

Among the projects that best interpret the tension of the opening up to the reality opposite, two are proposed here:

the redesign of the Reggio promenade made by Sandro Anselmi and the idea-project by Francesco Venezia for the symposium on the urban block ('isolato') of Messina.

As an average of the relationship between the tree-lined promenade, praised by D'Annunzio as the most beautiful kilometer facing the sea, and the changing line of the beach's shore lapped by the water of the Strait, the design tension of Alessandro Anselmi welcomed in the paths among the ruins (fig. $4 \mathrm{~b}$ ).

In an orthogonal direction to the coast there is the Messina's front placed by Francesco Venezia's project (fig. 4a) which makes in three-dimensions the riverbed of one of the Messina streams, the one called "Portalegni", by concluding it with the large overhanging building on the Strait, beyond the labile border of the shore. This terminal looks like a stretched building, in the hypothesis of potential replicas suggested by the natural landscape structure, which is marked by the streams orthogonal to the coast, and which would give the sense of overlooking the large water square of the Strait and beyond.
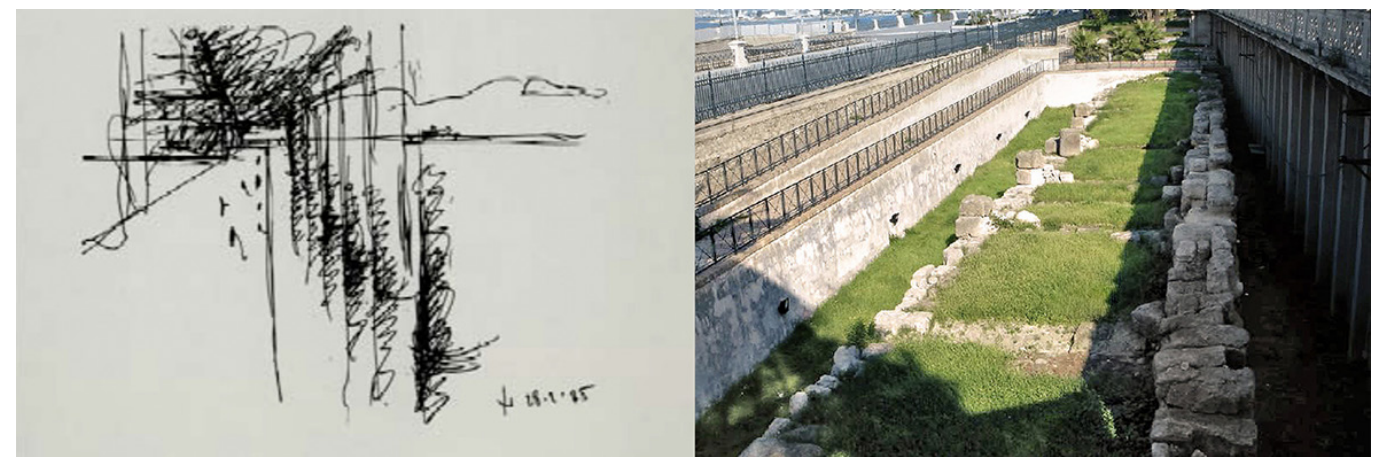

Sensitivity to the Modern

confirmed in restorations-rehabilitations of places in the Strait

There is no lack of relaunches made through the restoration of areas and buildings that testify to the recent past: at the lido in Reggio Calabria the Torre Nervi (fig. $5 c, d$ ) and at the most articulated fairground citadel in Messina some buildings of Adalberto Libera and the main portal (fig. 5a, b) whose restorations in progress, in line with regulatory adjustments, involve the Reggio's Purini-Thermes studio, that is assisted by Massimo Lo Curzio from Messina. The parts of already closed construction sites show together with the philological rigor, that belons to that sensitivity to conceptual deviations that has led to the necessary additions, adjustments to the requests for safety and energy saving regulations of which, here, we can say nothing more than " they are as if they have always been there", which gives more appreciation to the work done. 
Fig. 5. The Lido of Reggio Calabria and the Fairground of Messina: projects and restorations of Modern evidence on the Strait.

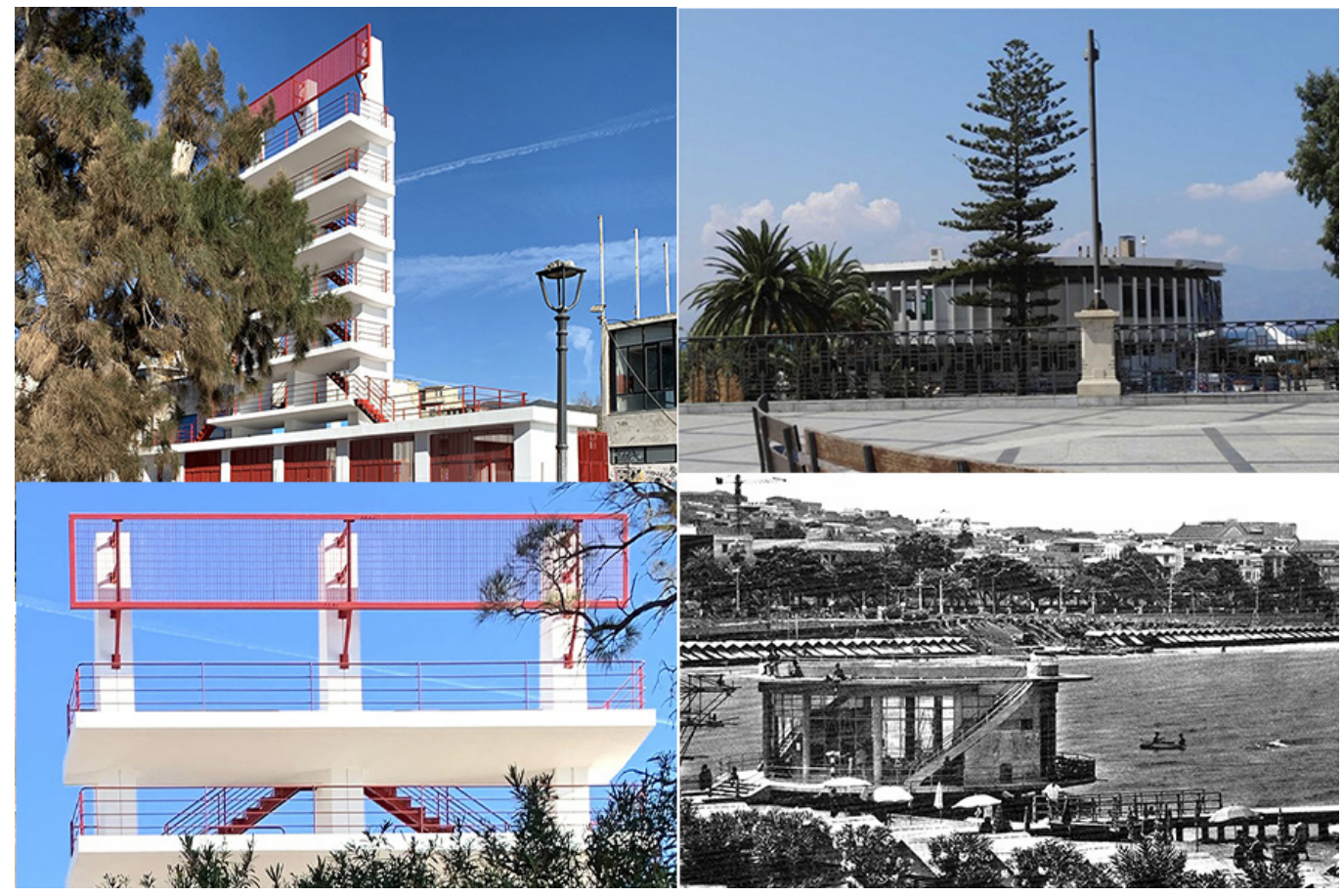

Door of the Strait

for a singular place

Actions left on paper do no less than testify to a degree of elaboration sensitive to the main features and to the history of the places. A very special example, chosen by location, concerned a design competition, called Capo Peloro, involving many professionals with ideas born from the intimate knowledge of the places.

I testify it from the inside, since I was part of a group that saw the aforementioned Prof. Mario Manganaro together with his new-found colleagues of studies in Rome: Professors Maria Anna Caminiti and Elena La Spada, belonging first to Architecture of Reggio Calabria and then to Engineering of Messina, together with more young staff, among whom I was. More and more issues were the themes of the competition project of our work group, that was presented with the motto "Arcalamecca", expression used in loco to express amazement for something of an astonishing beautiful and of main relevance in space: a "Phenomenon", like the Fata Morgana which, in particular weather conditions, shows the city and the coast upside down mirrored on the water, but also suspended in the sky.

The most natural action is the strengthening of the form of bond that the terraced house's ranks keep with the linear plots in identical thickness with the house, the front and back gardens tracing the agricultural textures of the plateau also containing the Ganzirri lakes. On the other hand, the "Finis Terrae", the architectures-places, are very special for the singularity of the specific extreme point that welcomes them: by listening to the sea, a "ear" formally shaped by a complex of meridians and by a small underwater observatory, like another shell, spirally shaped, that dives there, at Capo Peloro (fig. 6b).

Even more concise the intervention designed by Sandro Anselmi for the other jamb of the door of the Strait: at the top, the Scylla's Castle is already a significant presence and it needs nothing else but to be lit with figurations of the myth, which immediately provokes a chain of references. The myth and the life of this very special stretch of sea manned for precisely from Scylla and Charybdis (fig. 6a, b). 
Fig. 6. A design competition witnessing the strong link between life and myth on the Strait and an "enchanter lighthouse" on the Castle of Scilla.
Fig. 7. Buildings and other equipment that reconfigure urban structures by strengthening the places of comparison between the cities on the Strait: the "Palacultura" or the palace of culture

$(\mathrm{Me})$, the Offices of the Region (RC), the Tram line (ME), the Airport (RC) (composition).
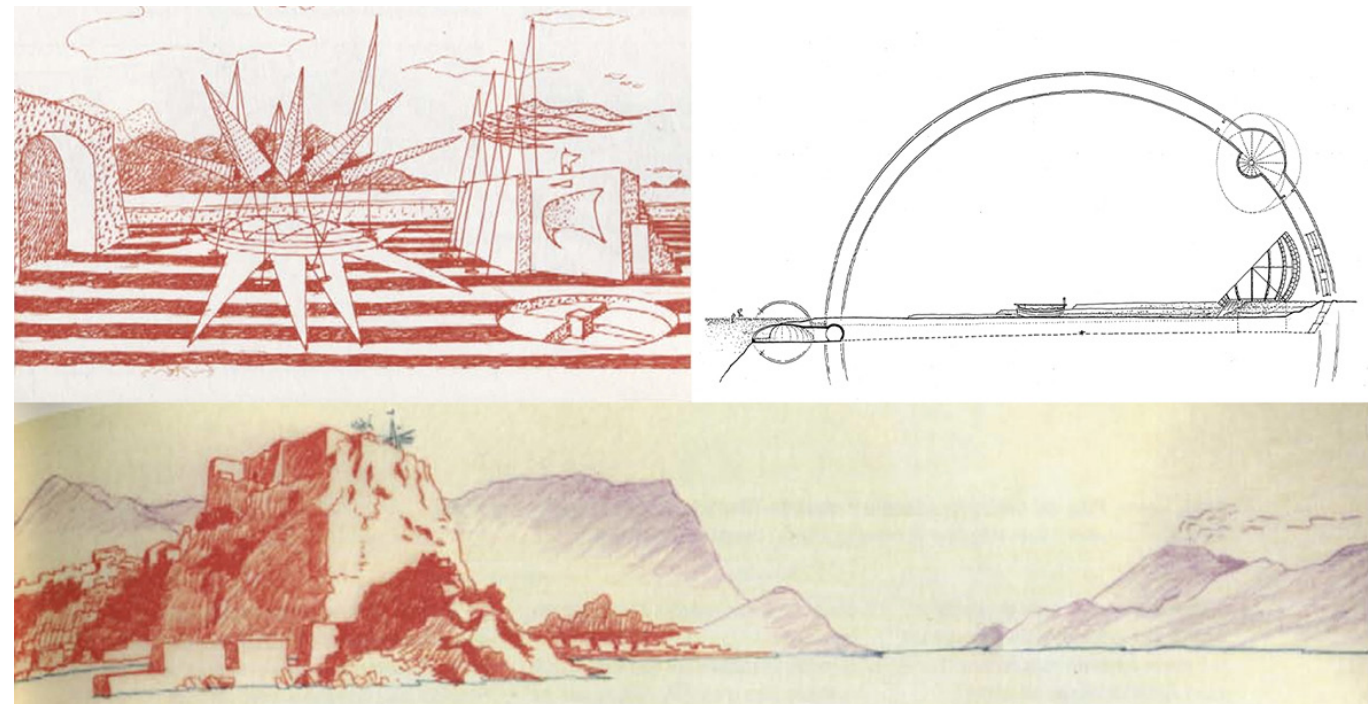

Urban reconfigurations:

public interventions, new equipment

Reggio Calabria (fig. 7), meanwhile, has consolidated its university center with the Architecture, Engineering and, on the higher hill, Agrarian campuses (fig. 7d). Jurisprudence has taken on consistency and occupied other buildings. The requests to host the Regional Council had a positive outcome with the new buildings, likewise the Headquarters (fig. $7 \mathrm{c}$ ). This has conferred a further structure to the city as also the new preparation of the Museum due to Piacentini that prestigiously relaunches the city among those of art, thanks to the collections concerning the Magna Greece.

Messina has equipped itself with the PalaAntonello (fig. 7b), a culture's palace which, together with the reborn Vittorio Emanuele Theater and the same name gallery, promises a rebirth and it appeal to its citizens to enjoy the city with greater intensity, now capable of hosting events which could potentially revive the past glories of being the place to the Film Festival that was held in the Fair's citadel in Messina and that now take place in Taormina. Urban mobility has also acquired a re-edition: its surface metro which quickly connects two of Messina's poles with its terminals distributed on the coast and which acts as an intermodal pole for the Cavallotti multi-storey car park (fig. 7a).
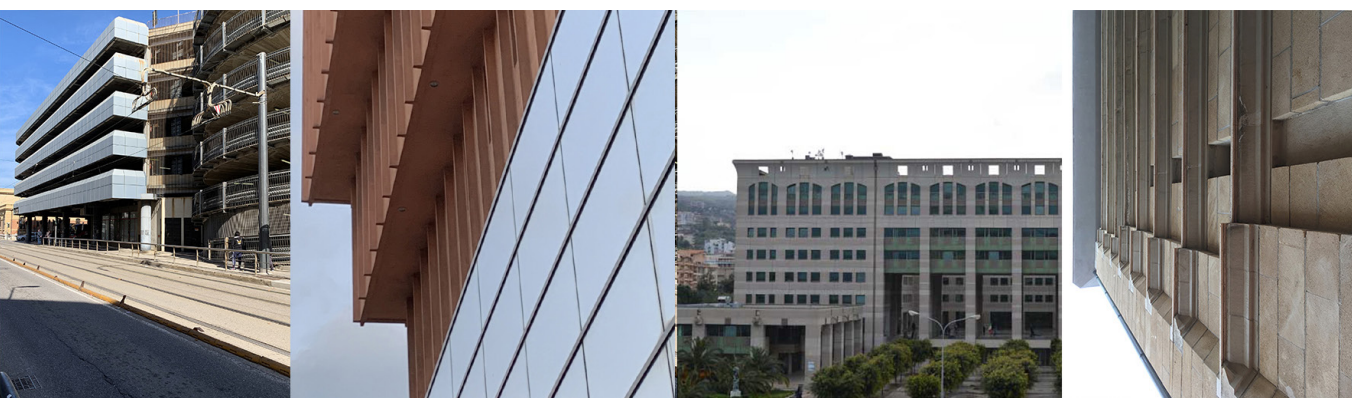

The Strait as a garrison for connection:

the Pylons of the former stable crossing of electricity as two panoramic towers for embracing the extension of the Strait in only one glance.

On both sides of the sea, the urban conurbation took place and now much more attention is paid to the fortresses, to the Umbertinian forts which, as object of study in the Woz workshops, will try to witness the impetus to a common destiny. They will do this by connecting 
Fig. 8. Large figures placed in eminent dislocations control the space of the Strait, embracing it in one single glance: they are the pillars of the former power line.

A little gaze launched

by the Pylons reads the

Ay the Pylons reads the

Strait.

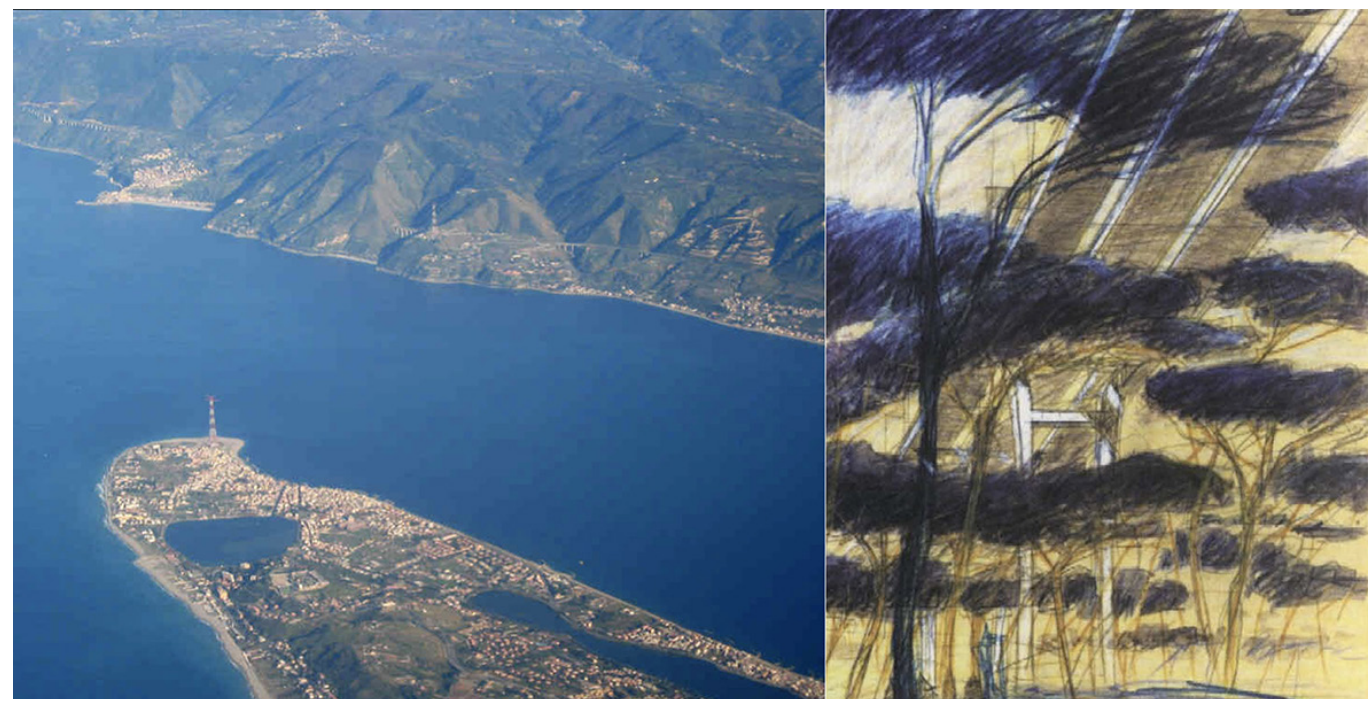

together the fortified structure in Piazza Castello, within the urban center of Reggio, the Castle of Scilla and the large figures designed by Alessandro Anselmi for the terrace overlooking the sea, as the extreme offshoot of the Strait to the north, marking the point beyond which, on the Calabrian front, it is no longer the Strait.

Silent witnesses of the only stable crossing no longer active as electricity bridge, the two Pylons, the Sicilian one sited on the tip of Torre Faro and the Calabrian other placed on the Santa Trada hill, as two extraordinary panoramic points (fig. 8a ) they confirm belonging to a single landscape, as asserted by the gaze that opens up from them.

A look that travels beyond the large water square, as its continuous crossings connect physically distant places and cultures, as distant as these mythical places were always, enchanted places which recall Scylla and Charybdis and that feed themselves with the legend of Colapesce.

The environmental impact, albeit mitigated as in the project by Alessandro Anselmi (fig. 8b) which at the moment keeps the stable crossing away, confirms at the same time the fragility and resistance of the places widely crossed by naval routes that went beyond the columns of Hercules, beyond the borders of the ancient world.

From the classical antiquity of the time of the myth, many civilizations have connected each others unceasingly, as it was evidenced by the flourishing studies of the universities on both sides, and many migrants of culture have been hosted, as it still happens that many stories still continue to intertwine each others.

\section{Conclusion}

The lands that were colonized by the migrations of the people came from the Greek city-states, whose protagonists mixed with the indigenous people, preserve the character of connecting people by mixing them and it also perpetuate the essence of witness of a multi-ethnic civilization in continuous mutation.

Author

Claudio Marchese, Università di Messina, cmarchese@unime.it

To cite this chapter: Marchese Claudio (2020). Lo Stretto:tensioni/The Strait (of Messina): tensions. In Arena A., Arena M., Brandolino R.G., Colistra D., Ginex G., Mediati D., Nucifora S., Raffa P. (a cura di). Connettere. Un disegno per annodare e tessere. Atti del $42^{\circ}$ Convegno Internazionale de Docenti delle Discipline della Rappresentazione/Connecting. Drawing for weaving relationships. Proceedings of the 42th International Conference of Representation Disciplines Teachers. Milano: FrancoAngeli, pp. 3443-3458. 